\title{
Socio-Economic Impact of Protected Cultivation on Tomato Growers of Himachal Pradesh
}

\author{
Kanika Mehta", Rajesh Kumar Thakur and J.S. Guleria \\ Department of Agricultural Economics, Extension Education \& Rural Sociology, CSK Himachal Pradesh Krishi Vishvavidyalya, \\ Palampur-176062, India
}

*Corresponding author: kanika.mehta9315@gmail.com (ORCID ID: 0000-0002-9623-1676)

Received: $16-08-2019$

Revised: $12-01-2020$

Accepted: $23-02-2020$

\begin{abstract}
Agriculture occupies the most prominent position in Himachal Pradesh, as it is the mainstay of more than 69 per cent of the state's population. Since the state is exposed to constraints such as shrinking land holdings coupled with perceptible changes in weather and climate, protected cultivation has emerged as the best alternative for using land and other resources efficiently. The main aim of this technology is to enhance the socio-economic conditions of the farmers. Therefore, the present study was conducted to analyse the cropping pattern, production and productivity of major crops being cultivated under protected conditions and to study its impact in crop productivity, employment and income (farm income and total household income) generation and income variability. In order to have a better insight, the factors under consideration were compared to the open-field conditions. The study is based on primary data collected through survey method for the agricultural year 2015-16. The data had been collected from 60 tomato (30 open-field and 30 polyhouse) growers, selected through proportional allocation method from Kangra District of Himachal Pradesh. The study revealed that protected cultivation had a significant impact in enhancing the crop productivity and was approximately three times higher in comparison to the openfield conditions. The labour utilization pattern on protected cultivation was found to be almost four times higher than that of the open- field cultivation indicating a significant contribution in enhancing the employment opportunities. The average farm and household income of the protected growers was observed to be increased by about 25 and 11 per cent, respectively with the adoption of protected technology in the study area. The income variability of the protected growers was also found to be less in comparison to the open-field growers indicating lesser risk and higher stability of income generated by the protected growers in the study area. Therefore, it can be concluded that protected cultivation has a significantly positive impact in improving the socio-economic conditions of the farmers in the study area and suits well to the agro-climatic conditions prevailing in the hilly areas like Himachal Pradesh.

\footnotetext{
Highlights

( Protected cultivation had a significant impact in enhancing the crop productivity, employment and income generation.

o Protected cultivation attains more stable income than open- field cultivation.
}

Keywords: Employment generation, farm income, household income, income variability, open-field cultivation, productivity, protected cultivation, tomato cultivation

Agriculture occupies the most prominent position in the economy of Himachal Pradesh as it is the mainstay of more than 69 per cent of the state's population. Efforts are afoot to make Himachal Pradesh self-sufficient in agriculture production and also in improving the economy of farmers.
The state has a great potential for producing horticultural crops especially vegetables in different seasons under varied conditions. Horticultural

How to cite this article: Mehta, K., Thakur, R.K. and Guleria, J.S. (2020). Socio-economic impact of protected cultivation on tomato growers of Himachal Pradesh. Economic Affairs, 65(1): 01-07. 
produce has high demand in the international markets in both fresh and processed forms (Kallega et al. 2015). With increase in economic standards, urbanization, international market integration and trade liberalization, the demand for horticultural products is expected to increase even further (Meena et al. 2016). The area, production and productivity of different vegetable crops in the state had shown a significant increase of about 51 per cent and 73 per cent, respectively in the last decade i.e. from the year 2005-06 to 2015-16. Moreover, the area and production under tomato in the state had also shown a significant increase by about 20 per cent and 61 per cent from 2005-06 to 2015-16, respectively (Department of Agriculture, Government of Himachal Pradesh, Shimla). There is still a vast scope for expansion of vegetables in the state as only about 10 per cent of the total cropped area has been brought under vegetable cultivation till now. The state is subjected to a great variation in agro-climatic conditions which ranges from subhumid sub-tropical to dry temperate zone and due to the extreme climatic conditions such as heavy rainfall, long winter season, high velocity winds, snowfall, frequent dry spells etc., the farmers cannot opt for cultivation of input sensitive and highly remunerative cash crops like vegetables and mostly are constrained to grow only one crop in a year with low levels of productivity. Therefore, in the present scenario of shrinking land holdings, coupled with perceptible changes in weather and climate, protected cultivation has emerged as the best alternative for using land and other resources efficiently.

Many state sponsored schemes have been implemented for the promotion of protected cultivation. The Departments of Agriculture and Horticulture as well as $12 \mathrm{KVK}$ s of 2 SAUs have worked together to make this enterprise a great success in the state besides being benefited from KVK-ATMA (Agricultural Technology Management Agency) convergence. The government is providing large scale subsidies to the farmers to popularize protected cultivation. Presently, 85 per cent project assistance (Dr. Y.S. Parmar Kisan Swarojgar Yojna) is being provided to the farmers. Also for the creation of water sources individually and collectively by a group of farmers (low/medium lift, pumping machinery), 50 per cent subsidy is being provided by the state. Protected cultivation technology aims at enhancing the socio-economic characteristics of the farmers and to generate a higher income, employment and a decent standard of living to the small and marginal framers of the state. Therefore, keeping in view the significance of protected cultivation in the state, the present study was conducted to analyse its socio-economic impact on the tomato growers with following specific objectives:

(i) To study the cropping pattern, production and productivity under protected cultivation and

(ii) To study its impact in crop productivity, employment and income (farm income and total household income) generation and income variability.

\section{MATERIALS AND METHODS}

The present study was conducted in Kangra district of Himachal Pradesh. This district was purposively selected for the study as among various districts of Himachal Pradesh, Kangra has vast potential for diversification and commercialization of agriculture through vegetable crops that are highly remunerative and best suited to hills and to the small sized land holdings. Moreover, the district is also having very high potential in protected farming and commands about 15 per cent of the total area under protected cultivation (259.63 ha) in the state. (Department of Agriculture, Government of Himachal Pradesh, Shimla).

Within Kangra district, the study was conducted in two blocks namely Baijnath and Bhedu Mahadev. Two-stage random sampling technique was followed to choose a sample of two development blocks in the first stage and the ultimate growers in the second and final stage of sampling. Out of these lists, random samples of 30 protected growers and 30 open-field growers were selected from the two blocks through proportional allocation method. To have a better insight, the protected growers were then post stratified into small $\left(<250 \mathrm{~m}^{2}\right)$ and large $\left(\geq 250 \mathrm{~m}^{2}\right)$ categories using cumulative cube root method. Thus, a total of 17 small and 13 large protected growers were found out of a sample of 30 . The primary data collected on survey schedules were tabulated to work out averages, ratios and percentages. The socio-economic aspects of tomato 
growers were studied through tabular analysis technique. The tabular analysis used for the study has been described below:

\section{Proportional allocation method}

The following formula was used for the selection of tomato growers from the selected blocks:

$$
n_{i}=\frac{N_{i}}{N} \times n \quad i=1,2
$$

where,

$n_{i}=$ Number of farmers to be sampled in $\mathrm{i}^{\text {th }}$ block

$N_{i}=$ Total number of farmers in $\mathrm{i}^{\text {th }}$ block

$N=$ Total number of open-field/ protected growers

$n=$ Total sample size to be chosen from the openfield/ protected growers

\section{Coefficient of variation}

In probability theory and statistics, the coefficient of variation, also known as relative standard deviation (RSD), is a standardized measure of dispersion of a probability distribution or frequency distribution. The coefficient of variability was used to analyse the income variability of the sample protected and open- field growers. The following formula was used:

$$
\text { C.V. }(\%)=\frac{S . D .}{\bar{Y}} * 100
$$

where,

C.V. is the coefficient of variation

S.D. is the standard deviation

$\bar{Y}$ is the mean of the mean/ average

\section{RESULTS AND DISCUSSION}

\section{Cropping pattern under protected conditions}

Protected cultivation is a specialized farming activity where in high value cash crops are grown. The selection of most profitable crops and cropping system holds the key for capital intensive venture. The cropping pattern followed under protected conditions has been shown in Table 1. On an average, per farm total cropped area under protected cultivation was estimated to be $332.77 \mathrm{~m}^{2}$. The maximum cropped area was found to be under tomato $(52.59 \%)$ followed by capsicum $(21.04 \%)$ and cucumber $(14.83 \%)$. The total cropped area under protected conditions on large farms was $507.46 \mathrm{~m}^{2}$ while that on small farms was $199.18 \mathrm{~m}^{2}$. Tomato was the predominant crop on both the small (50.50 $\%)$ and large farms (53.66 \%), respectively, which might be mainly due to more suitability of the crop in the study area. The overall cropping intensity was worked out to be 176.91 per cent and it varied from 172.11 per cent on large farms to 187.07 per cent on small farms, indicating towards more intensive cultivation by the small protected growers.

\begin{tabular}{|c|c|c|c|c|}
\hline $\begin{array}{l}\text { Sl. } \\
\text { No. }\end{array}$ & Crop & Small & Large & Overall \\
\hline 1 & Capsicum & $\begin{array}{l}35.00 \\
(17.57)\end{array}$ & $\begin{array}{l}115.85 \\
(22.83)\end{array}$ & $\begin{array}{l}70.03 \\
(21.04)\end{array}$ \\
\hline 2 & Tomato & $\begin{array}{l}100.59 \\
(50.50)\end{array}$ & $\begin{array}{l}272.31 \\
(53.66)\end{array}$ & $\begin{array}{l}175.00 \\
(52.59)\end{array}$ \\
\hline 3 & Cucumber & $\begin{array}{l}30.65 \\
(15.39)\end{array}$ & $\begin{array}{l}73.77 \\
(14.54)\end{array}$ & $\begin{array}{l}49.34 \\
(14.83)\end{array}$ \\
\hline 4 & Beans & $\begin{array}{l}22.35 \\
(11.22)\end{array}$ & $\begin{array}{l}26.15 \\
(5.15)\end{array}$ & $\begin{array}{l}24.00 \\
(7.21)\end{array}$ \\
\hline 5 & Others & $\begin{array}{l}10.59 \\
(5.32)\end{array}$ & $\begin{array}{l}19.38 \\
(3.82)\end{array}$ & $\begin{array}{l}14.40 \\
(4.33)\end{array}$ \\
\hline & $\begin{array}{l}\text { Total cropped } \\
\text { area }\end{array}$ & $\begin{array}{l}199.18 \\
(100.00)\end{array}$ & $\begin{array}{l}507.46 \\
(100.00)\end{array}$ & $\begin{array}{l}332.77 \\
(100.00)\end{array}$ \\
\hline & $\begin{array}{l}\text { Net cultivated } \\
\text { area }\end{array}$ & 106.47 & 294.85 & 188.10 \\
\hline & $\begin{array}{l}\text { Cropping } \\
\text { intensity (\%) }\end{array}$ & 187.07 & 172.11 & 176.91 \\
\hline
\end{tabular}

Table 1: Cropping pattern on sample farms under protected conditions $\left(\mathrm{m}^{2} /\right.$ farm $)$

Note: Figures in parentheses indicate percentages to the total in each category.

\section{Production and productivity under protected conditions}

Table 2 shows the production and productivity levels of major crops being cultivated under protected conditions in the study area. On an overall basis, cucumber gave the highest yield $\left(38.07 \mathrm{q} / 400 \mathrm{~m}^{2}\right)$ followed by tomato $(31.17 \mathrm{q} / 400$ $\left.\mathrm{m}^{2}\right)$ and capsicum $\left(21.92 \mathrm{q} / 100 \mathrm{~m}^{2}\right)$. In case of small farms, the productivity per $400 \mathrm{~m}^{2}$ for capsicum, tomato, cucumber and beans was estimated to be $25.83 q, 33.84 q, 37.20 q$ and $3.76 q$, respectively, while 
for large farms, it was $16.80 q, 27.68 \mathrm{q}, 39.20 \mathrm{q}$ and 4.88q, respectively. Sharma et al. (2013) also reported higher productivity for small polyhouse units in comparison to the large polyhouse units.

Table 3 reveals that protected conditions are having a significant impact in increasing the crop productivity by a minimum of 41.20 per cent (beans) and a maximum of 415.16 per cent (cucumber) as compared to the open-field conditions. On an average, the productivity obtained under protected conditions was approximately three times higher than that of the open-field conditions. Kumar and Arumugam (2010) and Kumar et al. (2016) also observed that the growth and yield parameters of different vegetables were significantly enhanced under protected over open- field. Similar results were also observed by Sethi et al (2003). Parvej et al. (2010) found that microclimatic variability inside polyhouse favoured the growth and development of tomato plant through increased plant height, number of branches per plant, rate of leaf area expansion and leaf area index over the plants grown in open field.

\section{Labourutilization pattern}

Protected cultivation is both capital and labour intensive avocation. Trained and skilled labour is one of the most important and critical resource for protected cultivation. Table 4 gives an overview of the operation-wise labour utilization pattern for tomato cultivation under sample protected units.
Table 4: Operation-wise labour utilization pattern for tomato cultivation under protected conditions (man days $/ 400 \mathrm{~m}^{2}$ )

\begin{tabular}{lllll}
\hline $\begin{array}{l}\text { S1. } \\
\text { No. }\end{array}$ & Particulars & Small & Large & Overall \\
\hline 1 & Nursery sowing & $\begin{array}{l}2.28 \\
(1.75)\end{array}$ & $2.56(2.23)$ & $2.4(1.94)$ \\
& & & \\
2 & Field preparation & 6.64 & $5.52(4.82)$ & $6.16(4.99)$ \\
& & $(5.09)$ & & \\
3 & Transplanting & $7.2(5.52)$ & $4.92(4.29)$ & $6.2(5.02)$ \\
4 & Irrigation/ & 27.48 & 28.56 & 27.92 \\
& Fertigation & $(21.07)$ & $(24.93)$ & $(22.60)$ \\
5 & Intercultural & 33.28 & 31.16 & 32.36 \\
& operations & $(25.52)$ & $(27.20)$ & $(26.20)$ \\
6 & Plant protection & 14.36 & $6.68(5.83)$ & 11.04 \\
& measures & $(11.02)$ & & $(8.94)$ \\
& (spraying) & & & \\
7 & Earthing up & $1.8(1.38)$ & $2.08(1.82)$ & $1.92(1.55)$ \\
8 & Harvesting/ & 37.36 & 33.08 & 35.52 \\
& Picking & $(28.65)$ & $(28.88)$ & $(28.76)$ \\
\hline & Total labour days & 130.4 & 114.56 & 123.52 \\
& & $(100.00)$ & $(100.00)$ & $(100.00)$
\end{tabular}

Note: Figures in parentheses indicate percentages to the total in each category.

Table reveals that on an overall basis, the total labor usage was 123.52 man days $/ 400 \mathrm{~m}^{2}$. The labour usage on an overall basis was highest in case of intercultural operations (32.36 man days $/ 400 \mathrm{~m}^{2}$ ), accounting for 26.20 per cent to the total and varied from 31.16 man days in large polyhouse units to 33.28 man days in small units, respectively. The

Table 2: Production and productivity of different crops under protected conditions

\begin{tabular}{lllllll}
\hline Crop & Small & & Large & & Overall \\
& $\begin{array}{l}\text { Production } \\
(\mathbf{q} / \mathbf{f a r m})\end{array}$ & $\begin{array}{l}\text { Productivity } \\
\left(\mathbf{q} / \mathbf{4 0 0} \mathbf{~ m}^{\mathbf{}}\right)\end{array}$ & $\begin{array}{l}\text { Production } \\
(\mathbf{q} / \mathbf{f a r m})\end{array}$ & $\begin{array}{l}\text { Productivity } \\
\left(\mathbf{q} / \mathbf{4 0 0} \mathbf{~ m}^{\mathbf{2}}\right)\end{array}$ & $\begin{array}{l}\text { Production } \\
(\mathbf{q} / \mathbf{f a r m})\end{array}$ & $\begin{array}{l}\text { Productivity } \\
\left(\mathbf{q} / \mathbf{4 0 0} \mathbf{~ m}^{\mathbf{2}}\right)\end{array}$ \\
\hline Capsicum & 2.26 & 25.83 & 4.87 & 16.80 & 3.39 & 21.92 \\
Tomato & 8.51 & 33.84 & 18.85 & 27.68 & 13.28 & 31.17 \\
Cucumber & 2.85 & 37.20 & 7.23 & 39.20 & 4.75 & 38.07 \\
Beans & 0.21 & 3.76 & 0.32 & 4.88 & 0.26 & 4.25 \\
\hline
\end{tabular}

Table 3: Comparative productivity of major crops under protected and open-field conditions ( $\left.\mathrm{q} / 400 \mathrm{~m}^{2}\right)$

\begin{tabular}{lllll}
\hline & & & \multicolumn{2}{c}{ Difference between protected and open-field conditions } \\
\hline Crop & Protected conditions & Open-field conditions & Absolute & $\%$ \\
\hline Capsicum & 21.92 & 8.95 & 12.97 & 144.92 \\
Tomato & 31.17 & 11.88 & 19.29 & 162.37 \\
Cucumber & 38.07 & 7.39 & 30.68 & 415.16 \\
Beans & 4.25 & 3.01 & 1.24 & 41.20 \\
Total & 95.41 & 31.23 & 64.18 & 205.51 \\
\hline
\end{tabular}


next highest labour usage was found to be on irrigation/fertigation purpose (27.92 man days/400 $\mathrm{m}^{2}$ ), accounting for 22.60 per cent, on an overall basis. The labour employed on irrigation/fertigation operations was found to be higher in case of large polyhouse units ( 28.56 man days $/ 400 \mathrm{~m}^{2}$ ) as compared to the small units (27.48 man days/400 $\mathrm{m}^{2}$ ), respectively. The table further revealed that the total labour usage for tomato cultivation was more on the small polyhouse units (130.40 man days $/ 400 \mathrm{~m}^{2}$ ) as compared to that of the large units (114.56 man days $/ 400 \mathrm{~m}^{2}$ ). Sharma (2012) also found high labour utilization for tomato cultivation under protected conditions.

Table 5: Comparative labour utilization pattern for tomato cultivation under protected and open-field conditions (man days/ $400 \mathrm{~m}^{2}$ )

\begin{tabular}{|c|c|c|c|}
\hline $\begin{array}{l}\text { Sl. } \\
\text { No. }\end{array}$ & Particulars & $\begin{array}{l}\text { Protected } \\
\text { conditions }\end{array}$ & $\begin{array}{l}\text { Open-field } \\
\text { conditions }\end{array}$ \\
\hline 1 & Nursery Sowing & 2.40 & 1.64 \\
\hline 2 & Field preparation & 6.16 & 2.91 \\
\hline 3 & Transplanting & 6.20 & 1.63 \\
\hline 4 & $\begin{array}{l}\text { Irriagation/ } \\
\text { fertigation }\end{array}$ & 27.92 & 6.65 \\
\hline 5 & $\begin{array}{l}\text { Intercultural } \\
\text { operations }\end{array}$ & 32.36 & 10.42 \\
\hline 6 & $\begin{array}{l}\text { Plant protection } \\
\text { measures }\end{array}$ & 11.04 & 2.83 \\
\hline 7 & Earthing up & 1.92 & 1.61 \\
\hline 8 & Harvesting/picking & 35.52 & 4.97 \\
\hline 9 & Total labour days & 123.52 & 32.66 \\
\hline
\end{tabular}

Table 5 gives a comparative analysis of the operationwise-labour utilization pattern for tomato crop under sample protected and open-field conditions. The table reveals that the labourutilization under protected conditions was almost four times higher than that of the open- field conditions. This clearly reveals that besides increasing the productivity, it is also expected to provide employment opportunities to the unemployed sector (at farmers' and service provider's level), thereby giving additional income to the farmers and their families. Spehia (2015) found high labor utilization for tomato cultivation under protected conditions. Kaur (2009) observed that human labour had a major share in total cost in all enterprise combinations in high-tech polyhouse. Sharma (2012) also observed that the protected cultivation generates on-farm employment to the extent of 126 days on small and 236 days on large category.

\section{Contribution of protected cultivation in gross farm income}

Table 6 reveals the contribution of protected cultivation on farm income and total household income of the sample polyhouse growers in the study area.

It can be seen from the table that average annual gross farm income of protected growers was ₹ $2,51,005$, at the overall level. Among the two categories, large protected growers had higher farm income (₹ 3,00,572) than small protected growers (₹ 2,10,732). Protected cultivation contributed about 19 per cent towards enhancing the gross farm income of small polyhouse growers and about 30 per cent in case of large growers, respectively. To sum up, it can be concluded that on an overall basis, the average farm income of the polyhouse growers was

Table 6: Contribution of protected cultivation in gross farm income of polyhouse growers

\begin{tabular}{|c|c|c|c|c|c|c|c|}
\hline \multirow{2}{*}{$\begin{array}{l}\text { Sl. } \\
\text { No. }\end{array}$} & \multirow[t]{2}{*}{ Particulars } & \multicolumn{2}{|c|}{ Small } & \multicolumn{2}{|c|}{ Large } & \multicolumn{2}{|c|}{ Overall } \\
\hline & & ₹/ farm & $\%$ to total & ₹/ farm & $\%$ to total & ₹/ farm & $\%$ to total \\
\hline 1 & Field crops & 25,738 & 12.21 & 28,744 & 9.56 & 27,041 & 10.77 \\
\hline 3 & Vegetables (excluding protected cultivation) & 69,779 & 33.12 & 70,696 & 23.53 & 70,176 & 27.96 \\
\hline 3 & Protected cultivation & & & & & & \\
\hline (i) & Capsicum & 7,910 & 3.75 & 17,045 & 5.67 & 11,865 & 4.73 \\
\hline (iii) & Cucumber & 8,550 & 4.06 & 21,690 & 7.22 & 14,250 & 5.68 \\
\hline (iv) & Beans & 735 & 0.35 & 1,120 & 0.37 & 910 & 0.36 \\
\hline & Sub total & 39,200 & 18.60 & 90,750 & 30.19 & 62,881 & 25.05 \\
\hline & Total farm income & $2,10,732$ & 100.00 & $3,00,572$ & 100.00 & $2,51,005$ & 100.00 \\
\hline
\end{tabular}

Source wise annual gross household income. 
Table 7: Contribution of protected cultivation in total gross household income of polyhouse growers (₹/ farm)

\begin{tabular}{llllll}
\hline & & & & \multicolumn{2}{c}{$\begin{array}{c}\text { Difference between protected } \\
\text { and Open-field conditions }\end{array}$} \\
\hline Sl. No & Particulars & Protected growers & Open-field growers & Absolute & $\%$ \\
\hline 1 & Farm income (excluding polyhouse income) & 188,124 & 224,514 & -36390 & -16.21 \\
2 & Polyhouse income & 62,881 & - & - & - \\
3 & Off-farm income & & & & \\
(i) & Service & 186,154 & 115,264 & 70890 & 61.50 \\
(ii) & Business (shop-keeping) & 77,400 & 40,967 & 36433 & 88.93 \\
(iii) & Pension & 70,800 & 45,322 & 25478 & 56.22 \\
(iv) & Artisans & - & 5,833 & - & - \\
(v) & Daily wage & 3,460 & 6,267 & -2807 & -44.79 \\
\hline & Sub total & 337,814 & 213,653 & 124161 & 58.11 \\
\hline & Total household income & 588,819 & 438,167 & 150652 & 34.38 \\
\hline
\end{tabular}

Table 8: Source-wise income variability on sample farms (₹/farm)

\begin{tabular}{llllll}
\hline & & \multicolumn{2}{l}{$\begin{array}{l}\text { Polyhouse growers (including } \\
\text { polyhouse income) }\end{array}$} & \multicolumn{2}{l}{ Open-field growers } \\
\cline { 3 - 6 } S1. No. & Particulars & Farm income & $\begin{array}{l}\text { Total household } \\
\text { income }\end{array}$ & Farm income & $\begin{array}{l}\text { Total household } \\
\text { income }\end{array}$ \\
\hline 1 & Mean & 251005 & 588818.99 & 224513.93 & 438166.83 \\
2 & Standard deviation & 59067.49 & 247727.68 & 111728.17 & 223438.93 \\
3 & Coefficient of variation $(\%)$ & 23.53 & 42.07 & 49.76 & 50.99 \\
\hline
\end{tabular}

increased by nearly 25 per cent with the adoption of polyhouse technology in the study area.

Income level on the sample farms clearly depicts their socio-economic status. Thus, it is very important to know the contribution of each one activity undertaken by family members to the household income. The annual gross household income of tomato growers under protected and open-field conditions has been divided into two major segments comprising farm income and offfarm income. The results are shown in Table 7. The total annual gross household income of the open-field and protected growers was found to be $₹ 4,38,167$ and 588,819 , respectively.

Field crops, vegetables and dairying together termed as farm-income were the most important contributor in the gross household income of open-field growers. The contribution of protected cultivation in total household income from all the sources was found to be about 11 per cent. The table further revealed that the total household income of protected growers was 34.38 per cent higher than that of the open-field growers. Similar results were also observed by Mwangi (2012), Singh et al. (2011) and Singh and Sirohi (2006). Therefore, it can be concluded that the protected cultivation had a significant impact in enhancing the total household income of tomato growers in the study area.

\section{Income variability}

In this section, an attempt has been made to identify the impact of protected cultivation in the stability of farm income and total household income. In order to have a better understanding, a comparative analysis was done for both the openfield and protected growers and the results have been presented in Table 8 . The results revealed that the income variability on farm income and total household income was higher in case of open-field growers in comparison to that of the protected growers. This is quite evident from the higher values of coefficient of variation in case of open-field growers $(49.76 \%$ and $50.99 \%)$ in comparison to the polyhouse growers (23.53\% and $42.07 \%$ ).

To sum up, the income variability of protected growers was found to be less in comparison to the open-field growers indicating lesser risk and higherstability of income generated by the protected growers in the study area. 


\section{CONCLUSION}

Protected cultivation technology aims at enhancing the socio-economic characteristics of the farmers and to generate a higher income, employment and a decent standard of living to the small and marginal framers of the state. Therefore, the present study pertains to analyse the socio-economic impact of protected cultivation on tomato growers of Himachal Pradesh. The study was based on the field level information collected from protected and openfield growers. The study revealed that protected cultivation had a significant impact in enhancing the crop productivity and was approximately three times higher in comparison to the openfield conditions. The labour utilization pattern on protected cultivation was found to be almost four times higher than that of the open-field cultivation indicating a significant contribution in enhancing the employment opportunities. The average farm and household income of the protected growers was observed to be increased by about 25 and 11 per cent, respectively with the adoption of protected technology in the study area. The income variability of the protected growers was also found to be less in comparison to the open-field growers indicating lesser risk and higher-stability of income generated by the protected growers in the study area. The total household income of polyhouse growers was 34.38 per cent more than that of the open-field growers. The study also observed less income variability of polyhouse growers in comparison to the open-field growers and therefore, it can be concluded that the risk in polyhouse income was low, having a positive effect in the stability of income generated by the polyhouse growers in the study area. Therefore, it can be concluded that protected cultivation has a significantly positive impact in improving the socioeconomic conditions of the farmers in the study area and suits well to the agro-climatic conditions prevailing in the hilly areas like Himachal Pradesh.

\section{REFERENCES}

Kallega, H.K., Kar, A. and Mathur, V.C. 2015. Temporal and Spatial Performance of Horticultural Crops in India. Economic Affairs, 60: 367-373.

Kaur, D. 2009. Economics of polyhouse technology in Una district of Himachal Pradesh. Thesis M.Sc. Department of Agricultural Economics, Extension Education \& Rural Sociology, CSK Himachal Pradesh Krishi Vishvavidyalaya, Palampur, India.
Kumar, P., Chauhan, R.S. and Grover, R.K. 2016. Economic analysis of tomato cultivation under poly house and open field conditions in Haryana, India. Journal of Applied and Natural Sciences, 8: 846-848.

Kumar, R.S. and Arumugam, T. 2010. Performance of vegetables under naturally ventilated polyhouse conditions. Mysore Journal of Agricultural Sciences, 44: 770-776.

Meena, S., Singh, I.P. and Meena, R.L. 2016. Cost of cultivation and returns on different cost concepts basis of onion in Rajasthan. Economic Affairs, 61: 11-16.

Mwangi, W.J. 2012. Comparative analysis of greenhouse versus open-field small scale tomato production in Nakuru-North district, Kenya. Thesis M.Sc., Department of Agricultural Economics and Agribusiness Management, Egerton University, Kenya.

Parvej, M.R., Khan, M.A. and Awal, M.A. 2010. Phenological development and production potentials of tomato under polyhouse climate. Journal of Agricultural Sciences, 5: 19-31.

Sethi, V.P., Tarsem, L., Gupta, Y.P. and Hans, V.S. 2003. Effect of greenhouse micro climate on the selected summer vegetables. Journal of Research, 40: 415-419.

Sharma, K.D., Pathania, M.S., Bala, B. and Gupta, M. 2013. Developing technologies for protected cultivation in Himachal Pradesh-economics and marketing strategies. Department of Agricultural Economics, Extension Education \& Rural Sociology, CSKHPKV, Palampur. Research Report, 66: 111-115.

Sharma, P. 2012. Financial viability of protected cultivation and its impact on farm economy in Mandi district of Himachal Pradesh. Thesis M.Sc. Department of Agricultural Economics, Extension Education \& Rural Sociology, CSK Himachal Pradesh Krishi Vishvavidyalaya, Palampur, India.

Sharma, P. 2012. Financial viability of protected cultivation and its impact on farm economy in Mandi district of Himachal Pradesh. Thesis M.Sc. Department of Agricultural Economics, Extension Education \& Rural Sociology, CSK Himachal Pradesh Krishi Vishvavidyalaya, Palampur, India.

Shende, N.V. and Meshram, R.R. 2015. Cost benefit analysis and marketing of tomato. American International Journal of Research in Formal, Applied E Natural Sciences, 11: 46-54.

Singh, A.K., Singh, B. and Gupta, R. 2011. Performance of sweet pepper (Capsicum annum) varieties and economics under protected and open field conditions in Uttarakhand. Indian Journal of Agricultural Sciences, 81: 973-975.

Singh, B. and Sirohi, N.P.S. 2006. Protected cultivation of vegetables in India: problems and future prospects. Actahorticulturae (ISHS). 710: 339-342.

Spehia, R.S. 2015. Status and impact of protected cultivation in Himachal Pradesh, India. Current Science, 108: 2254-2257. 
